
Mačković

\title{
Rusija kao podsvjesno Zapada
}

Članak je zadržan u integralnom obliku i odstupa od standardnog načina citiranja i navođenja izvora koji se primjenjuje u [sic]-u.

Već je odavno poznato da se frojdovska teorija podsvjesnoga nije ukorijenila u Rusiji te da se ta okolnost nikako ne može smatrati slučajnom: naprotiv, ona, možda više od bilo čega drugog, baca svjetlo na unutarnju strukturu ruske kulture $!^{[1]}$ Na Zapadu se u nekom smislu psihoanalizu može smatrati najraširenijom ideologijom. Ako pacijent po imenu Rusija nije pristao na psihoanalizu, to indicira da će analiza biti osobito zanimljiva budući da je u određenom smislu jedini predmet psihoanalize upravo odbijanje da se bude analiziran, odnosno odbijanje da se prizna vlastita determiniranost podsvjesnim.

Originalnost „ruske” pozicije, na kojoj su tradicionalne psihoanalitičke strategije lomile zube, između ostaloga sastoji se od toga što Rusija uopće ne inzistira na svojoj „svjesnosti”. Ruska kulturna tradicija, naprotiv, samu Rusiju poima kao podsvjesno: Rusija ne može imati podsvjesno jer je ona sama podsvjesno. Razumije se da se ova samosvijest kao podsvjesno u ruskoj kulturi ostvaruje u pojmovima koji nisu frojdovski, i da se ovu terminološku diferencijaciju ni na koji način ne smije zanemarivati. No ovdje bih htio u prvom redu demonstrirati bitnu sličnost „zapadnoga” diskursa o podsvjesnom, tj. nesvjesnom, i ruskog filozofskog diskursa o Rusiji, unaprijed se pomirivši s neizbježno opravdanim prigovorima o fragmentarnosti i jednostranosti, koji bi eventualno mogli izniknuti.

Rusiju kao filozofsku temu, kao što je poznato, otkrio je Čaadaev![2] Njegov je sud o stanju ruske kulture u to vrijeme bio percipiran (najblaže rečeno) površno te se i sada obično tako shvaća, kao politička kritika. Međutim, ta je kritika preradikalna da bi bila politička i već samim svojim radikalizmom prenosi diskurs na drugu razinu. Budući da, Čaadaev piše, „mi”, tj. Rusi, „ne pripadamo ni jednoj velikoj porodici ljudskog roda ${ }^{[3]}$, „stojimo gotovo pa izvan vremena”, „ne 
pripadamo ni Zapadu ni Istoku” (tj. također stojimo i izvan prostora), nemamo tako „ni zanosne uspomene, ni grandiozne predodžbe u sjećanju” (tj. sjećanja nema, ono je istisnuto, „izbrisano”), živimo u vremenskom razdoblju nalik onima koji su „prethodili suvremenom stanju našeg planeta”; i dalje: „mi” nemamo „ništa individualno na što bi se naša misao mogla osloniti”, nemamo tradiciju, moral, kulturu, dužnost, pravednost itd. Moglo bi se nastaviti s citatima, no ono najvažnije u njima je već jasno: okupljeni zajedno, oni predstavljaju klasičan opis podsvjesnoga koji je zapadna tradicija nudila od Schopenhauera, preko Hartmanna ${ }^{4]}$ i Nietzschea do Freuda.

U Rusiji, kako je opisuje Čaadaev, na vidjelo izlazi specifično proturječje: s jedne strane, ona je zemlja kao i svaka druga, koja ima određen prostor, povijest, narod koji je naseljava itd. S druge strane, Rusija se nalazi izvan prostora i vremena, izvan sjećanja, izvan prava, racionalne analize itd. Rusija „kao da ne ulazi u sastav čovječanstva, već postoji samo da bi svijetu zadala nekakvu važnu zadaću", tj. materijalno, izvanjsko postojanje Rusije samo je simptom, samo šifra koja mora biti objašnjena, psihoanalizirana. Drukčije rečeno, Rusija se nadaje ili kao predmet istraživanja ili kao onostranost koja izmiče svakom istraživanju. Ili još drukčije: Rusija je oblast diferencije, oblast ambivalentnosti, objektivnosti koja izlazi na vidjelo i koja se skriva, oblast „traga iščeznuća traga”, govoreći riječima Derridaa (tj. oblast iščeznuća „zanosnih uspomena i moćnih pouka”). No Rusija nije oblast subjektivnog, nije subjekt, svijest. Prostor Rusije prostor je gubitka prostora, gubitka prostorne određenosti, individualnosti. Vrijeme Rusije vrijeme je gubitka vremena, gubitka povijesti, sjećanja, „svjesnosti”. Rusija živi u post-povijesti (zato ona i može, kako predlaže Čaadaev u Apologiji, uzeti sve najbolje od drugih naroda, sve što su oni stvorili u povijesti - tema koja vodi i Leninu, i Stalinu, i „perestrojki”), no ona živi i u pred-povijesti, prije stvaranja svijeta. Rusija ništa ne „gradi”, budući da je kreativnost moguća samo unutar vrijeme-prostora individualnog ili kolektivnog osviještenog iskustva, ali sve tvorevine drugih naroda rastvaraju se u njoj, gubeći svoju određenost, i počinju ulaziti u proizvoljne sklopove: Rusija kao san, kao prostor i vrijeme sanjarenja, ali i kao oblast lakanovske psihoanalize, temeljene na slobodnom kombiniranju označitelja, poput prakse nadrealističkog „automatskog pisma” i sl.

U odnosu prema takvoj Rusiji, koja se razotkriva kao nesvjesno, sam Čaadaev nastupa u ulozi predstavnika europske svijesti. Drukčije rečeno, Drugo za Rusiju nije ono podsvjesno, već svijest. Zato u svojem Filozofskom pismu (rus. Filosofskoe pis'mo), upućenom ženi prvenstveno s ciljem 
zavođenja, Čaadaev apelira ne na skriveno erotično, već na svijest, red, organiziranost itd. Ruski intelektualac zavodi ženu prije svega svojom „svjesnošću” i potiče je da ne rodi tjelesni, već duhovni plod. Žena za ruskog mislioca nastupa samo kao simbolizacija Rusije koja obmanjuje: ona budi i istovremeno na sebe skreće njegovu erotsku energiju. Ruski je intelektualac, poput „ruskog Europljanina”, bitno androgin. Njegova „ruskost” i jest njegova anima, njegova ženskost. Zato se kod Čaadaeva i javlja tema ovladavanja samim sobom ili samodiscipline, koja se razvija u dijalogu sa ženom, no koja je u krajnjoj mjeri usmjerena na udaljavanje žene, na postizanje unutarnje samodostatnosti - figura koja će se poslije stalno ponavljati u ruskoj književnosti. U krajnje zaoštrenom obliku ova se tema pojavljuje kod V. Solov'eva ${ }^{[5]}$ ili kod Fedorova ${ }^{[6]}$ s njegovim maštanjima o samoporađanju koje jednom za svagda „kozmički” uklanja ženu i istovremeno označava konačan trijumf Rusije nad Zapadom: eros koji je usmjeren na ženu ili, što je isto, na reprodukciju kroz rođenje kantovskih „svjesnih” uvjeta prostora i vremena ${ }^{[]}$, poima se kao izričito „zapadni” - on mora biti preusmjeren na Rusiju i „narod”, kako bi se ukinuli prostor i vrijeme podjele, tj. individualizacije, i kako bi se realizirali prostor i vrijeme sanjarenja kao polimorfizam transformacija koje beskonačno traju, istovremeno bivajući kratkoročnima.

Ruski intelektualac na taj je način podijeljen između zapadnjačke svijesti i ruskog podsvjesnog. Do cjelovitosti on stoga može doći samo kroz ovladavanje cijelom svojom zemljom, kroz političkokozmičku gestu u koju se investira sav njegov eros. Pokušaj da mu se odvuče pažnja „ženskom pitanju $^{[8]}$ suprotstavljenim „pitanjem spola” može u tom kontekstu označavati jedino radikalnu ekspanziju Zapada ne samo u sferu njegove svijesti, nego i u sferu njegova podsvjesnog, što bi, u slučaju uspjeha takvog pokušaja, samo učvrstilo njegovu fundamentalnu unutarnju podvojenost. Zato cijepanje zapadnjačkog seksualno orijentiranog diskursa o podsvjesnom u Rusiji nije forma borbe svijesti s podsvjesnim, već borba, takoreći, jednog podsvjesnog s drugim. Upravo zbog toga, uza svu radikalnost takvog cijepanja, diskurs o Rusiji, zbog kojeg ovo cijepanje nastaje, može se lako prekodirati u kvazierotičan diskurs. Tako je zanimljivo primijetiti da integriranju intelektualca u „partijsku organizaciju” Lenin suprotstavlja zapadnjačku prostituciji9] , a Malevič, premda tvrdi da na njegov crni kvadrat nikome neće poći za rukom smjestiti nježan osmijeh Psyche ili ga pretvoriti u prostirku za ljubavne užitke, svojim vlastitim interpretacijama crnoga kvadrata tjera na razmišljanje da se ovdje ne radi samo o prostoru gubitka svake predmetne individualnosti, tj. o 
specifično „ruskom” prostoru, nego i o crnoći nekakve kozmičke pravagine. Što se tiče, primjerice, epohe ruskog simbolizma, zna se da je ona napravila profesiju upravo iz takve vrste prekodiranja uz to da je Zapad na specifičan način samog sebe objedinio s „Istokom” prema obilježju odustajanja od primata podsvjesnog u korist svijesti (koje se izravno pripisivalo zapadnoj filozofiji i budizmu), a Rusija je na taj način iznova bila istjerana u prostor i vrijeme s onu stranu povijesti. Uostalom, takva konfiguracija suprotstavljenih podsvijesti puno je manje egzotična nego što se možda čini. Jasno je da su filozofska pisma Čaadaeva reakcija na filozofiju povijesti u njemačkom idealizmu, prema kojoj svjetski duh na putu pronalaženja vlastite samospoznaje prolazi kroz razne susljedne etape. Pritom se svaka od njih vezuje uz određeno razdoblje kulturnog, a posebice filozofskog razvoja različitih naroda, koji upravo zahvaljujući toj povezanosti čine jedinstveni „ljudski rod". U toj schellingovsko-hegelovskoj epopeji za Rusiju nije bilo mjesta: odsutnost povijesnog mjesta u njezinom je slučaju završna presuda, s obzirom na to da je svjetski duh u njemačkom idealizmu već došao do samosvijesti: izgubljeno vrijeme ne može se vratiti, prostor odsutnosti ne može se popuniti, a eksteritorijalnost i ekstemporalnost Rusije ukazuju na njezin transcendentalni i eshatološki poraz i prokletstvo. Čaadaev se s potpunom filozofskom ozbiljnošću posvetio otkrivanju Rusije kao apsolutnog Drugog koje se nalazi izvan granica misli, kao prostoru nesvjesnog.

Međutim, to otkriće drugoga umjesto razuma u njegovu završnom obliku, u njegovoj samospoznaji, nakon pomnijeg je promatranja predstavljalo ne toliko presudu Rusiji, koliko pronalazak ograničenosti samog razuma: ako se nešto nalazi izvan razuma, to ne dokazuje samo da zahtjevi razuma nisu utemeljeni, nego i da on ovisi o određenom mjestu koje zauzima. Ukazujući na to da djelovanjem razuma upravlja „unutarnja sila” i da ta „pokretačka i oživljujuća sila ne proizlazi iz misli”, Kireevskij ${ }^{[10]}$ tvrdi: „Ta unutarnja priroda razuma obično mimoilazi pozornost zapadnjačkih mislioca. ${ }^{\circledR 11]}$ Ovdje se neumanjiva heterogenost ruskog filozofskog razmišljanja Rusije pretvara u nesvodivu heterogenost unutar same filozofske misli: unutarnjim razvojem filozofske misli izvana upravlja sila koja je izvan kontrole mislilaca. Ono što se nalazi „unutar unutarnjeg” zapravo je izvanjsko, objektno: posebna konfiguracija „europske obrazovanosti” određuje njezin način razmišljanja. No ta konfiguracija može se opisati samo izvana, odnosno iz Rusije. Prednost „ruske obrazovanosti" temelji se upravo na tome što je ona istovremeno jednaka zapadnjačkoj, odnosno 
kršćanskoj, ali i drugoj, tj. „istočnoj”. Zahvaljujući takvoj konfiguraciji, pred njom se otkriva prostor „S onu strane” filozofije, koji je u načelu zapadnom razumu nedostupan, dijalektički nesvodiv, nemonološki, heterogen, podsvjestan. Upravo u tome i leži suština slavenofilskog argumenta kojim se Čaadaev koristi u svojoj Apologijij ${ }^{12]}$ : prednost Rusije nije posebnost njezine kulture, nego nedostatak takve posebnosti ili ,jednostranosti”. U Rusiji tako skrivena mehanika razuma postaje vidljiva, a posljedično joj se otvara i mogućnost upravljanja razumom. „Svjesvjetska toplina ruske duše“ upravo se i odnosi na takvu nedeterminiranost vlastite svijesti, koja omogućuje razumijevanje i determiniranje tuđe svijesti: samo onaj tko nema svoju dušu može postati inženjer ljudskih duša.

Spoznaja da je ono što je svijesti „izvanjsko” i heterogeno u suštini zapravo svijest unutar determinirajućeg, tj. podsvjesno, svejedno nije sasvim originalna, no nalazi se u temeljima cjelokupnog posthegelovskog filozofskog razmišljanja sve do suvremenosti. Među primjerima prvih manifestacija podsvjesnog može se spomenuti „volja” Schopenhauera, „egzistencija“"Kierkegaarda (ovdje se postavlja pitanje o sudbini pojedinca koji se nalazi izvan okvira hegelovskog sustava), kasna filozofija Schellinga, koja je izravno utjecala i na rusko slavenofilstvo i na marksizam, a u kojem je ulogu Rusije odigrala radnička klasa (u hegelovskom sustavu za radnike također nije bilo mjesta: upravo se zato ona, na temelju istog argumenta zbog kojeg je prozvana „zapadnjačkom”, proziva „buržoaskom” itd.). Freudova psihoanaliza samo je jedna od manifestacija takve vrste posthegelovske misli, koja znatno ovisi o već postojećoj schopenhauerovskoj i nietzscheovskoj tradiciji. Etape koje dolaze nakon nje su strukturalizam, kritička rasna teorija, heiddegerizam, dekonstruktivizam itd.

Za rusko je otkriće podsvjesnog specifično prije svega to što se kao signatura podsvijesti i mjesto diferencijacije pojavljuju država, geografija, prostorno-vremenska konfiguracija, „kronotop”. Kao što znamo, korelat je te konfiguracije na psihičkoj razini poznata sobornost ${ }^{[13]}$. Sobornost' je ruski naziv za libido, eros, jezik, želju za vlašću, epistemu, klasnu svijest, arhetipe, diferenciju, simulaciju itd. Upravo je sobornost' ona unutarnja sila koja očiglednim elementima razuma ukazuje na njihovu očiglednost, logičkom zaključku na njegovu uvjerljivost, empirijskim dokazima na njihov empirizam, argumentima srca na njihovu srčanost itd. Sobornost' našoj svijesti stvari pokazuje onakvima kakve one zaista jesu, bivajući pritom sama sakrivena. Ako se sobornost' iskrivi, i stvari će se 
iskriviti. No razum ne može primijetiti njihovu iskrivljenost jer ih on vidi onako kako se one njemu predstavljaju: on sam ne može promišljati silu koja mu stvari pokazuje takvima kakvima se one njemu pokazuju, tj. on sam ne može promišljati sobornost'.

Sobornost' svemu određuje mjesto u odnosu na druge. Ona jest, kao što je već rečeno, prije svega prostorno-vremenska kategorija: onaj tko u usporedbi s drugima stoji „najpravilnije”, taj i stvari vidi „bolje od svih”; onaj tko „ne zna gdje mu je mjesto” ne vidi stvari onakvima kakve jesu. Koncept sobornosti je, naravno, crkveno-povijesnog podrijetla i svjedoči o specifičnoj konfiguraciji ruske misli o podsvjesnom: raskol ličnosti na svjesnu i podsvjesnu sferu kao koncept postoji još od ranih slavenofila u ideji „nerazdijeljenosti i nepovezanosti” istovremeno ljudske i božanske prirode Krista, kojoj odgovara i dvojna priroda kršćanina - sudionika i u svjetovnom i u crkvenom životu - kao i dvojna slika odnosa između tri hipostaze Sv. Trojstva. Upravo sobornost' i jest ona crkvena komponenta svijesti (koju određuje tajanstvenost sakramenta pričesti), koja kao ono nesvjesno ili podsvjesno određuje „svjetovnu” usmjerenost razuma. Sobornost' u nekom smislu kod slavenofila ima prioritet nad sadržajem, tj. dogmatizmom vjere, s obzirom na to da taj dogmatizam i jest rezultat crkvenih sabora, na kojima se sobornost' i prikazivala kao doracionalna orijentiranost razuma prema istini. Bez obzira na to što se sobornost' prividno poziva na crkvenu tradiciju, ona u njoj ne zauzima nikakvo mjesto. To nije slučajno jer njezina funkcija i jest da „daje mjesto”. Sobornost' se poistovjećuje i s Kristom, i s Bogorodicom, i s „majkom vlažnom Zemljom”, i s Duhom Svetim, i s mističnom „unutarnjom Crkvom”, dok se kod Solov'eva, primjerice, pojavljuje i kao novi mitologem, kao Sofija, koja pak, iznova kreće u igru poistovjećivanja. No, prvotna diferencija kod svih tih primjera poistovjećenja svejedno se zadržava: sobornost' zaista nadvladava raskol između Zapada i Istoka, između vjere i ateizma, između ruskosti i europejstva, između svjesnog i podsvjesnog; zato njezino mjesto i jest izvan svakog prostora, uključujući i prostor teološke misli. Drugim riječima, njezino je mjesto tamo gdje je i Rusija, tj. s onu strane eshatologije. Dominantna pozicija koju tema Rusije zauzima u ruskoj misli, tako da „ruska filozofija” obično stupa kao sinonim za „filozofiranje o Rusiji”, ne bi trebala dovoditi u zabludu u odnosu na pripadnost ovog rusko-filozofskog diskursa „magistralnoj liniji” europske filozofske misli posthegelovskog, tj. postmetafizičkog, posthistorijskog, postracionalističkog i postprosvjetiteljskog razdoblja. Zapadnjaci su, sa svojom filozofskom kritikom Rusije, kroz povijest zaostajali za slavenofilskom „ruskom” 
kritikom filozofije koja je bila varijanta općeeuropskog kriticizma. Specifično ruska u toj situaciji bila je samo unutarnja razjedinjenost samog filozofiranja na takoreći etničkoj razini. Ako europska filozofija, počevši već od prosvjetiteljstva, postavlja pitanje o Drugom i podvrgava „europocentrizam” zapadnjačke kulture kritici, ta kritička struja, orijentirana na Drugo, na „drugu kulturu", objektivno služi za univerzalizaciju same europske kulture ili, drugim riječima, za europski imperijalizam. U tim je uvjetima jedinstveno, zaista nereducirujuće Drugo (budući da ono iznutra dijeli sāmo filozofiranje i ne podliježe imperijalističkoj ekspanziji) - seksualno drugo, libido, erotska Želja za vlašću, diskurs koji stoga i postaje dominantan na Zapadu.

Ruski je intelektualac, naprotiv, sam rascijepljen na „europsku svijest” i njezino „rusko Drugo” - i to mu je dovoljno za neko vrijeme bez ikakvog libida. Ukoliko se Rousseau prepuštao vizijama o Indijancima, njemačka filozofija o Indijcima, Gaugin o Polinezijcima, Picasso o Afrikancima itd., ruski intelektualac postao je kentaur sastavljen od Rousseaua i Indijanca, Schopenhauera i Indijca, Picassa i Afrikanca (stvarna situacija ruske avangarde s njezinim interesom prema ikoni, natpisima, lubok[14] itd.). U svojem vlastitom „drugom” Rus je spoznavao viziju europske filozofije, a u sebi samome - realizaciju njezinih ideala. Iz kritičkog principa po kojem „podsvjesno određuje svjesno” (ili „bitak određuje svijest”, „instinkt klase određuje svijest” itd.) ruski je intelektualac dijelio s europskom mišlju modernističke epohe; on je, dakako, zaključivao: „Rusija (kao podsvjesno) određuje Europu (kao svjesno)”, ili točnije: „Rusija mora određivati Zapad”. Za Freuda, kao rezultat psihoanalitičke terapije, ,ja” treba stajati na mjestu „onoga”, tj. podsvjesnoga. Za Marxa pobjeda proletarijata također označuje i pobjedu „uzdignutog” njemačkog idealizma, koji je postao „svjesno od klase” i smijenio „nesvjesno” buržoaskog „robnog fetišizma”. Ako postmodernistička, poststrukturalistička misao ovdje vidi kombinaciju „falokracije” i imperijalizma i govori o „nereducirujućoj heterogenosti Drugog”, koja ne podliježe ni seksualnoj ni revolucionarnoj „akviziciji”, onda to Drugo tu postaje „apsolutno Drugim”, javlja se u nedostižnoj udaljenosti: predmet se skriva iza predmetnosti, bit otklizava i postaje fundamentalno nedostižnom. Upravo zbog te apsolutne udaljenosti predmet, bit, žena i sl. dodjeljuju se u isto vrijeme apsolutnom vlašću nad „ja”, dekonstruiraju „ja”, postaju za njega „apsolutno bliskim” te ga intimno određuju.

Rusija je, s druge strane, od samog početka u ruskoj misli figurirala kao pobjednički, određujući početak: kao predmet, bit, žena itd., koja gospodari nad europskim nadmenim „ja”. Međutim, 
problem leži u tome što je odgovarajuća vizija Rusije moguća samo u perspektivi europske misli: pobjeda Drugog, tj. Rusije nad Zapadom, moguća je jedino kao efekt unutarnje pobjede ruske inteligencije, tj. zapadnjačkog principa, zapadnjačke spoznaje u samoj Rusiji. Rusija je odgovorila na zapadnjački ekspanzionizam strategijom samookupacije, samokolonizacije, samoeuropeizacije. U situaciji postmodernističke paradigme ta je strategija već osuđena na propast: ispostavlja se da je ruska inteligencija izgubljena u Drugom, tj. u Rusiji, bez šanse za svoju aktivaciju. Suvremena pometnja umova u ruskoj inteligenciji posljedica je toga što je Zapad već pretrpio poraz, metafizika je već dekonstruirana, svjesno se već otopilo u nesvjesnom - i Zapad se u tome ponovno snašao bez Rusije. U određenom se smislu ponavlja prvotna konfiguracija, koju je u svoje vrijeme postavio Čaadaev: Rusija nije dobila svoj udio u zapadnoj posthistoriji na isti način zbog kojega ga nije dobila ni u zapadnoj povijesti. Moguće je da se ponovno ocrtavaju granice postmodernističkog mišljenja: ako je prije univerzalizam povijesnog duha bio upitan, budući da u sebi nije zahvatio Rusiju, sada se po istoj osnovi sumnji može podvrgnuti i univerzalizam postmodernog beskonačnog i neutažive žudnje, univerzalizam erosa, jer diferencija koja ga konstituira i čini da i posjedovanje i zadovoljstvo budu nemogući nalazi na ograničenje u ruskoj indiferentnosti, koja i jedno i drugo lišava smisla.

U svakom slučaju, „kriza erosa” ili „kriza podsvjesnog”, kojoj trenutno svjedočimo u zapadnjačkoj misli u obliku paranoidnog rasta njihovog značenja, direktno utječe i na „rusku ideju”. Njezina pripadnost sferi težnje prema podsvjesnomu (prema postmodernističkom razumijevanju: težnje koja gubi svoj objekt) u ruskoj je filozofiji najavljena već, u najmanju ruku, u radu Vladimira Solov'eva Kriza zapadne filozofije (1874.). Tim radom započinje druga etapa u razvoju ruske ideje, u kojoj započinje igra izjednačavanja i razlikovanja s drugim europskim diskursima o nesvjesnom. Temeljni patos Solov'evljeva eseja nalazi se u potrazi za sintezom između sobornosti slavenofila i „filozofije nesvjesnog” Eduarda von Hartmanna, Schopenhauerova učenika. Nesvjesno Schopenhauera i Hartmanna Solov'ev interpretira kao „djelomičnu” ili „jednostranu” interpretaciju sobornosti ${ }^{15]}$ ili, kasnije, same Sofije. Od načela negacije i duhovnog i materijalnog svijeta nesvjesno se pretvara u nositelja utopijskog, eshatološkog erosa: ono se, govoreći suvremenim jezikom, „teritorijalizira” u procesu mitologizacije Rusije. Za Solov'eva je karakteristično da ne shvaća „tjelesni” eros kao „djelo trećega”, nego kao idealno tijelo partnera (tijelo koje bi „doista bilo 
moguće voljeti”), tj. načelo rođenja zamjenjuje se načelom produciranja, okultizmom. Ili, rječnikom suvremenih skeptika, realnost se ovdje zamjenjuje simulacijom. Rusija, doživljavajući svoj prostor kao „prazan”, kao prostor čistog nesvjesnog, ovdje proglašava da joj je cilj emanirati u taj prostor posve umjetnoga svijeta, nakon što „dostigne i prestigne” zapadnjački tehnički progres. To tehnizirano nesvjesno i njegove manifestacije zatim postaju središte teorije i prakse ruske avangarde koja se preko Maleviča definira kao „upravljanjem nesvjesnim ${ }^{\lceil 16]}$ (kod Solov'eva: „upravljanje utjelovljenjem religiozne ideje”).

Solov'ev postavlja osnovni model za recepciju zapadnjačkih teorija nesvjesnog u Rusiji: ako one Zapadu predstavljaju prijetnju, za Rusiju vrijedi suprotno - obećanje pobjede nad zapadnjačkom spoznajom. Ako su na Zapadu one antireligiozne, u Rusiji posredstvom slavenofilske sobornosti čine korak prema pravoslavlju. Ukratko, na sjecištu ruske duhovno-državne granice mijenjaju znak i smjer. Sličnu reinterpretaciju Schopenhauera moguće je pronaći kod Tolstoja („volja” Schopenhauera reinterpretira se „pozitivno” kao „nesvjesni” život ruskog seljaštva, lišen „principa individualnosti" s njegovim negativnim posljedicama), Fedorova (životna stanka reinterpretira se „pozitivno” kao preusmjeravanje volje od života k uskrsnuću) itd. Jasno je da je najuspješnija u tom kontekstu bila recepcija Nietzschea.

Nietzscheovo „dionizijsko načelo” simbolisti su shvatili kao svjedočenje da je Zapad priznao princip sobornosti kao obećanje konačne pobjede, u koju su već počeli sumnjati. Što se tiče nietzscheanskoga „nadčovjeka”, njega je već Solov'ev poimao kao korak prema Bogočovjeku Kristu. ${ }^{[17]}$ Sada nemamo mogućnosti ulaziti u dobro poznati, iako jedva shvatljiv - i jedva uopće dostupan razumijevanju - karneval maski koji su simbolisti inscenirali: s Rusijom, Prekrasnom Damom, Sofijom, njihovim demonskim ili „zapadnjačkim” dvojnicima itd. Dovoljno je reći da je sva ta igra bila vrlo erotizirana te da je sve bilo spremno za dolazak Freuda. Njega je i asimilirao Bahtin upravo po tom modelu: frojdovsku je svijest Bahtin optužio da je previše svijest, previše jednosmjerna, polemična, negativna itd.[18] Istodobno je u njegovoj vlastitoj teoriji karnevala ona bila reinterpretirana „pozitivno” kao „narodno” (tj. rusko) „u velikom prostranstvu - vremenu”, „neslužbeno” itd. Erotično istjerivanje podudara se ovdje s političkom, i još dublje, s prostornovremenskim „izvannalaženjem” same Rusije, na kojoj je insceniran karneval europske kulture. Polimorfizam same bahtinovske teorije, koji je dublji od teorije o polifoniji romana, izvire iz figure 
koja se Bahtinu otkrila pod utjecajem već akumuliranih suparničkih teorija podsvjesnog. Prema Bahtinu, ako na razini „ideologije” ili svijesti likovi u romanu vide jedan u drugom „drugog” i ulaze jedan s drugim u dijaloge, onda se u figuri „autora” kod Bahtina spajaju crte sobornog Bogočovjeka, kierkegaardskog egzistencijalnog lika, Freudova psihoanalitičara, Nietzscheova nadčovjeka, Marxova vođe - analitičara i manipulatora, avangardnog kolažista itd.: dijaloga među njima (dijaloga među romanima, a ne unutar romana) nema i ne može biti zato što su svi oni manifestacije jednog te istog principa pozitivno shvaćenog nesvjesnog. Ili, drukčije rečeno: svi su oni utopljeni u bezličnost sovjetsko-ruskog prostačko-političkog vica.

Podrazumijeva se da bez obzira na njezino cijelo značenje u ruskoj kulturi, sinteza erotičnog podsvjesnog u Rusiji kao uistinu podsvjesnog nije mogla imati u ruskoj povijesti takvu ulogu kao sinteza ruskog mita i marksizma. Ideja o tome da „bitak određuje svijest” neobično je bliska „religioznom realizmu” slavenofilske tradicije, koja je u suprotnosti sa zapadnjačkom idealizmom. Ako su na početku Rusija i proletarijat još konkurirali, već se 30-ih godina povijesni materijalizam podređuje dijalektičkom materijalizmu, odnosno društvena povijest - kozmičkome procesu, kako ga je shvaćao, ako želite, već Solov'ev. U to vrijeme službena ideologija traži formule poput sljedećih: „nacionalno po formi i socijalističko po sadržaju” ili „partijnost i narodnost”, kojima je cilj u sebi spojiti obje podsvijesti - proletersku i rusku.

Trenutno misao o podsvjesnom prolazi kroz krizu - u formi njezine radikalizacije. Suvremena francuska misao sažela je modernističku tradiciju u barem dva odnosa: prvo, našla je mogućnost govoriti u sličnim terminima o svim ranije konkurentnim teorijama podsvjesnog, što je moguće koristiti također i u diskursu o Rusiji, i drugo, naučila je govoriti o podsvjesnom kao o apsolutno Drugom, neprepoznatljivom i nesvodivom, što se, ako ćemo govoriti konkretno o frojdizmu, pojavilo u kritici njegove tradicionalne pozitivne strategije u Lacana, Deleuzea i Derridaa.

Istodobno, to jedinstvo diskursa o Drugom nasljeđuje jedinstvo metafizičkog diskursa o Jednom. Izuzetnu, providnu ulogu Rusije moguće je argumentirati jedino ako je Rusija jedinstvena metafizička regija u svijetu, što je tvrdio i Hegel: odatle unutarnja ovisnost „ruske ideje” o jednoj ili drugoj formi hegelijanizma. Istu tu unutarnju ovisnost o Hegelu uočili su marksizam, frojdizam, egzistencijalizam itd., zbog toga što je svaki od njih ukazivao na jedinstvenu zonu koju nije uključila (i koju nije mogla uključiti) metafizika. Zbog toga je suparništvo između tih teorija prirodno, 
suparništvo čiji je dio prošlosti istiskivanje frojdizma u Rusiji. I tada, kada se otkriva sličnost među svim tim diskursima, ona postaje povod za nastanak jedinog i jedinstvenog diskursa o Drugom, kao ipak jedinstvenoj drugoj „monološkoj” metafizici.

Međutim, hipoteza da je „metafizika” ili „ideologija” potpuno apsorbirala svijest još se uvijek čini naglom. Individualnoj se svijesti pokazuje još uvijek nečvrsto polje intelektualnih dokaza, preko kojeg ona može prijeći samo ako je nešto pokreće - nešto skriveno od nje same, a dovoljno razrušena, kontradiktorna ili općenito heterogena množina teorija, zapažanja, tekstova, tradicija i sl. Strategije koje se koriste kako bismo se u cijeloj toj raznovrsnosti orijentirali, kako bismo u njoj odredili vlastito mjesto, identificirali se s njezinim elementima, ili obrnuto, diferencirati se od njih, također su raznovrsne, iako ih se može u osnovnim crtama opisati. Međutim, takav opis, koji pretvara proces individualizacije u neku osmišljenu strategiju podređenu određenim pravilima, čini svaku teoriju podsvjesnog viškom, budući da svaka ta teorija polazi od činjenice individualizacije kao od praiskonskog, spontanog, uspostavljenog u samom postojanju nereflektirajućeg uvjeta svake spoznaje i svake uopće svjesne radnje. U stoljeću nastanka genetskog inženjeringa taj se prioritet rođenoga nad proizvedenim (ili erosa nad tehnikom) čini već dosta problematičnim. Ako se učenje o erosu i učenje o Rusiji razlikuju na razini njihovih pretenzija, oni se podudaraju na razini strategija koje su iz njih nastale, što potječe od „izvannalaženja” europskih kulturnih institucija ruskog slavenofila i bečkog Židova - ta je sličnost, premda neprepoznata, naznačena već u samoj ruskoj kulturnoj tradiciji, kako smo prethodno prikazali. Kako se ne bismo izgubili usred kontradiktorne raznovrsnosti kulturnih institucija i zahtjeva, kako im se ne bismo podredili, kako se ne bismo u njih integrirali, ostali bez vlastite volje i izbora, potrebno je prije svega na njih gledati kao na nekakvo jedinstvo: jedino takav pogled daje mogućnost onomu koji gleda da zauzme „vlastitu poziciju”, ili „metapoziciju”, izvanjsku i autoritetnu u odnosu na vidljivu kulturu. Upravo se takva strateški oblikovana metapozicija „koja nadvladava kontradiktornosti” kulture potom obznanjuje u hipostaziranoj formi kao „podsvijest” te kulture, kao njezino Drugo, tj. jedinstvenost kulture nastaje u istom trenutku kada i njezino Drugo. Ili obrnuto: „idealno” i „svjesno” - istodobno s „materijalnim” i „nesvjesnim”.

Za Freuda brisanje ili ignoriranje suprotnosti znak je rada podsvjesnog, dinamike htijenja, logike sna. Hegelov sustav, stvoren nekoć davno kako bi pomirio tada dosta zaostalu njemačku i 
europsku civilizaciju, koji pokreće mehanizam uzimanja i svladavanja proturječnosti, vjerojatno je iz te perspektive shvaćen kao poklapanje realnosti i sna, logike misli i logike želje, glasa i erosa, svijesti i podsvijesti. Njemačka je već bila reformirana poslije napoleonskih ratova te joj je cilj bio pomiriti se s tom novom realnošću, zaželjeti je, „vidjeti je u snu”.

No bečki Židov Freud imao je šanse jedino u realno, „materijalno” transformiranom čovječanstvu. Materijalizacija njegove vlastite želje mogla se održati jedino ako se iza savršenstva i želje mogao očitati materijalni supstrat. (Slična je situacija bila i kod Marxa, za kojega je materijalni supstrat hegelovske dijalektike postao „prijatelj”, ili proletarijat.) U Freudovoj je psihoanalizi proces svladavanja suprotnosti dobio taj materijalni supstrat u „libidinoznoj ekonomiji”, koja dopušta da se libido investira u prividne, na svjesnoj razini, logički nesjedinjavajuće znakove. Te se, običnim logičnim tokom „potisnute” misli sinteze, ti takoreći otpaci logički organizirane civilizacije, tijekom psihoanalize i uz pomoću „mehanizma prijenosa” moraju transportirati u svijest doktora ili točnije, u samu ličnost doktora, u njegovu vlastitu materijalnost, kako bi u njoj našle potvrdu - to je procedura koja objašnjava vlast doktora nad pacijentom. Prostor istisnutog, izbačenog (ne smješta slučajno Duchamp pod utjecajem Freuda u prostor umjetnosti „smeće civilizacije”, počevši na specifičan način, od pisoara) ovdje se pojavljuje kao analogija prostoru obredne žrtve: razum doktora preuzima kontrolu nad svijetom samo onda kada njegovo tijelo postaje tijelom tuđe želje, prostorom razvoja libidinoznih transformacija, „drukčije podsvijesti”.

Ta ista tema hegelovske dijalektike od samoga početka opčinjava rusku misao. Već prvi slavenofili opisuju rusko pravoslavlje kao dokidanje suprotnosti između zapadnog katoličanstva i protestantizma, to jest kao mjesto materijalizacije onoga što je skriveno, kao paradoksalno jedinstvo (zapadne) Crkve, koje savladava misaonu, logičku podjelu, ili kao nekakvu noć kršćanstva, koja mora prijeći u vječni dan. O sintezi idealnog kao o karakteristično ruskoj ideji govori Solov'ev, i nakon njega oblik te ideje na različite načine mijenja cijela ruska religiozna renesansa, pri čemu se on kod mnogih (na primjer, kod Merežkovskog ili Rozanova) povezuje s očekivanjem nekakvog kozmičkog braka između duha (muški europski princip) i tijela (ženski ruski princip). Rusija se pritom prikazuje kao mjesto realizacije zapadnoga erosa, njegove fantazme o posljednjoj sintezi, koje su potisnute u logičkoj zapadnoj civilizaciji. Interpretacija „ruske misli” iz perspektive predložene „strateške analize” na taj način dopušta konkretiziranje značaja 
podsvjesnog, koje reprezentira Rusija - ta tuđa, zapadnjačka podsvijest, koju ona mora izbaviti iz svojega tijela kako bi dostigla pobjedu nad Zapadom na razini svijesti ili na razini realnosti.

Ista se strategija nalazi i u ruskom marksizmu. Kao i za slavenofile, i za Lenina je simbol „buržoaznosti” i „idealizma” - ,jednostranost”, to jest dosljedno logičko mišljenje, koje se temelji na principu sličnosti i na zakonu izostavljenog trećeg. Njemu, kao i hegelovskoj idealističkoj dijalektici Lenin suprotstavlja „dijalektiku samog života”. Ovdje vitalizam, koji nesumnjivo izvire iz nietzscheanstva (utjecaj nietzscheanstva vidljiv je i u pozitivnoj instrumentalizaciji Leninova shvaćanja „ideologije”, koje u klasičnom marksizmu nastupa kao čista negativnost), zauzima mjesto marksističkoga rada: ruska se revolucija pretvara u činjenicu kozmičkog života, koja ukida carstvo buržoaske, to jest pozitivne logike.

Ta se tendencija prema pretvaranju marksizma u jezik htijenja uzakonjuje u staljinističkom dijalektičkom materijalizmu s njegovim „zakonom jedinstva i borbi suprotnosti”. Rusija, koja je država dijalektičkog materijalizma, ovdje se definitivno pokazuje kao svijet onirističkih priviđenja, poput svijeta s onu stranu zrcala, poput prostora mistično-erotske ekstaze, pritegnutoga seksualnim činom (,jedinstvom i borbom” muških i ženskih načela). Ne počinje se slučajno u to vrijeme o Rusiji govoriti kao o mjestu „utjelovljenja vječne mašte cijeloga čovječanstva o divnom životu". Oblikovana u 30-im godinama estetika socijalističkog realizma sa svojim vodećim principom „socijalističko po sadržaju i realistično (ili nacionalno) po obliku”, u kojem svođenje „realizma” ili „nacionalnosti” na razinu „forme” već dovoljno svjedoči o tome kako ovdje riječ nije o realizmu kao o mimezi, nego o „realizacijama” kolektivnih sanjarenja, otkriva očitu bliskost s pravcima koji su niknuli gotovo paralelno - nadrealizam, magični realizam itd., što nas vraća Freudu. U isto vrijeme Bahtinova teorija karnevala, koja ambivalentno komentira staljinističku kulturu, pokazuje bliskost teoriji „transgresije” Georgesa Bataillea, koja tako pak ambivalentno komentira, u otprilike isto vrijeme, umjetničku praksu nadrealizma.

U svjetlu ranije spomenutih paraleli, ispostavlja se da su i frojdovska psihoanaliza i „ruska ideja” (koja nije dopustila njegovo neposredno usvajanje) doista produkti veoma sličnih strategija, koje razlikuje (ako, razumije se, krajnje pojednostavimo) samo to što je „deteritorijalizirani” Židov Freud na raspolaganju za teritorijalizaciju tuđih potiskivanja imao samo svoje vlastito tijelo, dok je ruska filozofija za isti cilj na raspolaganju imala prilično veliki kolektivni prostor. U svakom su slučaju te 
strategije bile orijentirane na „tuđe“ i nisu bile određene nekakvim posebno svojim - psihološkim ili nacionalnim - izvornim, nerefleksivno zadanim sadržajem: psihološko i nacionalno ovdje se nadaju samo na razini forme.

Obje su strategije tipične za ponašanje skorojevića koji teži uspjehu, to jest za otkrivanje onoga što „postaje” ili „je postalo” usred onoga što „je bilo” ili što „jest”. Ali skorojevićka je situacija, razumije se, prilično univerzalna. Budući da nadvladava opreku između „božanskog i životinjskog”, čovjek je već sam po svojoj prirodi skorojević, pa i sama je priroda skorojevićka jer želi nadvladati opreku između „postojanja i ništavila”. Problem ruske filozofije svodi se na to da je ona bila filozofija skorojevića u potrazi za pravom prvorodstva, i rješenje je tog problema u tome što je svaka filozofija takva potraga.

1989.

Izvor: Grojs, Boris. 2003. Iskusstvo utopii. Gesamtkunstwerk Stalin. Stat'i. Pragmatika kul'tury, 2003, str. 150-67.

Prevele: Ana Haramustek, Ivana Klešković, Klara Kolar, Karla Kosić i Dominik Mačković 
[1] Usp. Pjatigorskij, A. 1977. O psihoanalize iz sovremennoj Rossii. U: Pjatigoskij, A. Rossija/Russia. Torino. Str. 29-50.

[2] Petr Jakovlevič Čaadaev (1794. - 1856.) bio je ruski mislilac, politički djelatnik i društvenopolitički aktivist. Rođen u plemićkoj obitelji, sudjelovao je u napoleonskim ratovima (1812. - 1814.) te putovao po Europi (1823. - 1826.), gdje se upoznao i sa samim Schellingom. Kao pripadnik progresivnog plemstva koje se intelektualno formiralo pod utjecajem europskog prosvjetiteljstva i ruskog antifeudalnog pokreta Čaadaev je bio povezan s pokretima dekabrista i ruskih „zapadnjaka”. Kao mislilac traži neosporne zakonitosti historijskog razvitka, na kojima bi provođenje društveno-političkih promjena bilo zasnovano. Žestoko kritizira rusku autokraciju, pravoslavlje i feudalni sistem. Kasnije se odriče revolucije kao metode uvođenja političkih promjena te se okreće katoličanstvu i uvjerenju da je istinski nosilac promjena moralno-religiozni preodgoj čovječanstva u katoličkoj vjeri (op. prev.).

[3] Čaadaev, P. Ja. 1987. Stat'i i pis'ma. Moskva. Str. 36.

[4] Eduard von Hartmann (1842. - 1906.) bio je njemački filozof, najpoznatiji po svojoj knjizi Filozofija nesvjesnoga (njem. Philosophie des Unbewußten) iz 1869., u kojoj povezuje misli Hegela, Schellinga i Schopenhauera. Prema Hartmannu, počelo je svijeta volja i duh, no kao nesvjesno samoga sebe. Ovo počelo svijeta („apsolutno”) u povijesti mora biti dovedeno do svijesti u razumskom tumačenju (op. prev.).

[5] Vladimir Sergeevič Solov'ev (1853. - 1900.) bio je ruski pjesnik, religiozni mislilac i filozof. Kao mislilac se formira pod utjecajima budizma, neoplatonizma, grčkih crkvenih otaca, pravoslavlja i njemačkog idealizma. Po društveno-političkoj liniji bio je blizak ruskim „slavenofilima”. Ključan pojam njegove misli ideja je racionalnog i empirijski nespoznatljivog „sve-jedno bitnog” (rus. vseedinoe suščee). Ono je sfera božanskoga koja određuje sebi podređen realni svijet. Spoznaje se „potpunim znanjem” (rus. cel'noe znanie) koje obuhvaća empirijsku, racionalnu i mističku spoznaju. Ovime se postiže jedinstvo znanosti, filozofije i teologije koje Solov'ev naziva „slobodnom teozofijom” (rus. svobodnaja teosofija). Solov'ev je zagovarao ujedinjenje zapadne i istočne kršćanske crkve pod pokroviteljstvom monarhijskog državnog uređenja u ostvarenju kojega 
bi glavnu ulogu igrao upravo ruski narod. Ovime bi se ostvarilo takozvano „carstvo božje” (rus. carstvo bož'e) na zemlji kao društveno-politički ideal (op. prev.).

[6] Nikolaj Fedorovič Fedorov (1829. - 1903.) bio je ruski religiozni filozof i utemeljitelj ruskog kozmizma. Radio je kao provincijski profesor povijesti i geografije te kao knjižničar u Moskvi. Ovdje, primajući goste i raspravljajući o različitim temama, dobiva nadimak „moskovski Sokrat”. Fedorov je glavno zlo u ljudskom životu vidio u fizičkom propadanju i smrti. Čovjeka suprotstavlja prirodnim silama, vjerujući da će razvojem znanosti i tehnike čovjek prevladati vlastitu smrtnost, podrediti prirodu svojoj volji i naposljetku ovladati kozmosom. Po dostizanju besmrtnosti čovječanstvo više neće biti razdirano nikakvim nejednakostima, nepravednostima i neprijateljstvima. Fedorov je vjerovao u ostvarenje besmrtnosti praktičnim sredstvima u ovome životu, zbog čega odbacuje tradicionalno kršćanstvo, zamjenjujući ga religijom štovanja predaka. U političkom smislu Fedorov je bio konzervativac. Kamen temeljac svoje utopističke vizije budućnosti vidio je u društvu koje je organizirano na patrijarhalno-rodbinskom načelu, suprotstavljajući ga „nebratskom” (rus. nebratskoe) načelu koje je osnova suvremene (zapadne) civilizacije (op. prev.).

[7] Ovdje se radi o prostoru i vremenu kao čistim formama osjetilnoga zrenja u Kantovoj epistemologiji, kako je primarno izložena u njegovoj Kritici čistoga uma. Prostor i vrijeme spoznajnom su subjektu inherentni načini obrađivanja „sirove” osjetilne građe kao rezultata podražavanja osjetila od strane (nespoznatljive) stvari o sebi. Oni predstavljaju osnovni način predočavanja svijeta od kojega se ni na koji način ne može apstrahirati. Grojs ovdje na nejasan način piše o Kantu i njegovoj transcendentalnoj estetici, nazivajući spomenute pojmove „svjesnima”. Koristeći pridjev „svjesni” (rus. soznatel'nyj), Grojs ukazuje na racionalistički orijentiran način razmišljanja kojim se Zapad razlikuje od Rusije. Ovaj pojam također je smješten u psihoanalitički kontekst Grojsova teksta, u kojem se pojmovi „svjesno”, „podsvjesno” (rus. podsoznatel'noe) i nesvjesno (rus. bessoznatel'noe) međusobno podrazumijevaju i imaju svoje značenje jedni u odnosu na druge. Ne radi se o tome da Grojs krivo interpretira Kanta, već o tome da u svojem tekstu „žrtvuje” filozofsku egzaktnost u korist osebujnosti izraza, što je trebalo naglasiti kako bi se izbjegli mogući nesporazumi (op. prev.).

[8] O specifičnosti „Ženskog pitanja” usp. osobito Paperno, I. 1988. Chernyshevsky and the Age of Realism. Stanford. 
[9] Lenin, V. I. 1957. Partijnaja organizacija i partijnaja literatura. U: V. I. Lenin ob iskusstve i literature. Moskva. Str. 43.

[10] Kireevskij, Ivan Vasil'evič (1806. - 1856.) bio je ruski filozof, književni kritičar i publicist; jedan od osnivača filozofije slavenofilstva.

[11] Kireevskij, I. V. 1911. O novyx načalah filosofii. U: Kireevskij, I. V. Polnoe sobranie sočinenij v 2-h tomah. Moskva.

[12] Odnosi se na Apologiju luđaka (Apologija sumasšedšego, 1837.), Čaadaevljevo djelo koje je nastalo kao reakcija na to što su ga prozvali ludim (op. prev.).

[13] Detaljnije smo značenje riječi sobornost' objasnili u prijevodu teksta M. Ėpštejna Amerusija. Na hrvatski bi se jezik riječ mogla prevesti kao sabornost ili komunalnost, no odlučili smo se na čuvanje ruskog originala kako bi se sačuvalo bogatstvo konotacija ruske riječi (op. prev.).

[14] Lubok je naziv za popularan tiskani materijal koji se pojavio u drugoj polovici 17. stoljeća, a karakterističan je po svojim jednostavnim crtežima i pričama, obično književne, religiozne ili narodne teme.

[15] Solov'ev, V. 1966. Krizis zapadnoj filosofii. U: Solov'ev, V. Sobranie sočinenij v 12 t. T. 1. Bruxelles. Str. 99-100.

[16] Malevič, K. S. 1980. Vvedenie v teoriju pribavočnogo èlementa v živopisi. U: Malevič, K. Die gegenstandlose Welt. Berlin.

[17] Solov'ev, V. Ideja sverhčeloveka. U: Solov'ev, V. Op. cit. T. 9. Str. 265-278.

[18] Bahtin, M. M. - Vološinov, V. N. 1983. Frejdizm. New York. Str. 158-162. Podsvjesno se tu opisuje kao projekcija svijesti liječnika tijekom psihoanalitičke seanse.

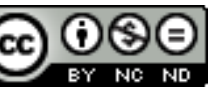

Creative Commons Attribution-NonCommercial-NoDerivatives 4.0 International License 